УДК 658.147:621

Хілуха Оксана,

кандидат економічних наук, доцент, Східноєвропейський національний університет імені Лесі Українки, кафедра економіки, безпеки та інноваційної діяльності підприємства, м. Луцьк; ORCID ID 0000-0002-9059-7271, e-mail: Oksana.Hiluha@eenu.edu.ua

https://doi.org/10.29038/2411-4014-2020-03-92-96

\title{
КОРПОРАТИВНИЙ РОЗВИТОК УПРАВЛІНСЬКОГО МИСЛЕННЯ
}

У статті визначено сутність категорії мислення, що пов'язана з інтелектуальною діяльністю людини, $є$ вищою формою творчої активності, що полягає у здійснені наукової, інноваційної, організаційно-економічної діяльності та розв'язує нове науково-прикладне завдання. У публікації розвинуто такі види мислення: теоретичне та практичне; репродуктивне і продуктивне (творче); наочно-образне, словесно-логічне і наочнодійове; аналітичне (логічне, рекурсивне) і інтуїтивне; дивергентне і конвергентне. Управлінське мислення характеризується пізнанням сутності, виявленням закономірностей, аналізом, узагальненням, систематизацією одержуваної інформації менеджерами та на цій основі прийняттям управлінських рішень, керуючись професійними знаннями і управлінським досвідом.

Ключові слова: управлінське мислення, корпоративний розвиток, управлінські рішення, менеджер, лідерські якості.

Хилуха Оксана, кандидат экономических наук, доцент,

Восточноевропейский национальный университет имени Леси Украинки, кафедра экономики, безопасности и инновационной деятельности предприятия, г. Луцк

\section{КОРПОРАТИВНЫЙ РАЗВИТИЕ УПРАВЛЕНЧЕСКОГО МЫШЛЕНИЯ}

В статье определена сущность категории мышления, которая связанная с интеллектуальной деятельностью человека и является высшей формой творческой активности, выраженная в осуществлении научной, инновационной, организационно-экономической деятельности, порождает решение нового научноприкладной задачи. В публикации развито такие виды мышления : теоретическое и практическое; репродуктивное и продуктивное (творческое) наглядно-образное, словесно-логическое и нагляднодейственное; аналитическое (логическое, рекурсивное) и интуитивное; дивергентное и конвергентное. Управленческое мышление характеризуется познанием сущности, выявлением закономерностей, анализом, обобщением, систематизацией получаемой информации менеджерами и на этой основе принятием управленческих решений, руководствуясь профессиональными знаниями и управленческим опытом.

Ключевые слова: управленческое мышление, корпоративное развитие, управленческие решения, менеджер, лидерские качества.

Khilukha Oksana, candidate of sciences (Economics), associate professor, Lesya Ukrainka Eastern European National University, Department of Economics, Security and Innovation,

Lutsk

\section{CORPORATE DEVELOPMENT OF MANAGEMENT THINKING}

Introduction. Nowadays, the most crucial case for corporations is sustainable corporate development. The request for the improvement of the competitiveness of businesses is projected into requests for individual managers. The requirements made on managers are called managerial competences. The skills most often recognized as vital to the 
manager's success appear to be proper choices, given the discussion of the qualities needed for a skill to be sufficient. The potential of a manager is regarded as a basis for the rise of such skills. The successful manager's performance is accomplished by the development of his potential. The primary source of such growth is management thinking. It includes management knowledge, skills, and experience by directors and has been identified as a significant factor to ensure that. Management thinking helps an organization to solve its difficulties related to asymmetries and uncertainty. Companies that integrate management thinking will create a competency that improves the abilities, knowledge, and behaviors managers need.

The purpose of the article highlight challenges and recommends future investigation avenues that will expectedly further enrich management thinking.

Results. It investigates how management thinking reveals itself in management practice in the corporation. The paper defines management thinking as the process of creating, implementing, integrating, and evaluating information to capture and control complex problems. It is also an essential form of creative activity. The publication develops the following types of thinking: theoretical and practical; reproductive and productive (creative); visual, verbal-logical, and visual-action; analytical and intuitive; divergent and convergent.

Conclusions. Management thinking identifies, analyses, generalizes, synthesizes information, and helps make decisions based on professional knowledge and management experience.

Keywords: managerial thinking, corporate development, management decisions, manager, leadership qualities.

Постановка проблеми. Інтеграція вітчизняних корпорацій в міжнародний економічний простір вносить свої вимоги до їх реформування. В сучасних умовах становлення менеджера неможливе без чіткого визначення системи знань, умінь і навичок, особистісних якостей фахівця його професійних компетентностей. А його управлінська діяльність визначається рівнем розвитку його управлінського мислення. Систему менеджменту можна вважати ефективною, коли іiі результатом є компетентна особистість, що володіє не тільки знаннями, професіоналізмом, високими моральними якостями, але вміє діяти адекватно у відповідних обставинах, застосовувати свої знання, беручи на себе відповідальність за свою діяльність, що є результатом мислення компетентного менеджера.

Управлінське мислення як критерій розвитку компетентності менеджерів організації формується на основі прийняття ними управлінських рішень. Це вимагає розглянути сутність управлінського мислення, виявити його особливості, закономірності та принципи розвитку в контексті професійної діяльності менеджера.

Аналіз останніх досліджень і публікацій. Дослідженнями у яких покладено початок розв’ язання проблеми, що відображає різні аспекти феномена «мислення, як внутрішнього характеру (якості) особистості» є праці учених найбільш відомими серед них є: логічна теорія мислення О. М. Леонтьєва [8]; теорія поетапного формування розумових дій П. Я. Гальперіна [2]; теорія формування здібностей у зв'язку з особливостями мислення С.Л.Рубинштейна [10] і Б.М. Теплова [9].

Логічна теорія мислення знайшла своє відображення у працях вітчизняних та зарубіжних учених-економістів таких як М. Заяць, який проаналізував значення інформаційних технологій у формуванні стратегічного мислення менеджера [5]. І. А. Цюрко, який сформував модель керівника, який має орієнтуватися як на роботу 3 персоналом, так і на реалізацію стратегії ефективного управління підприємством [11].

Е. Джулакідзе, Е. Барбакадзе зазначив, що для розробки правомірного рішення необхідно адекватно розглядати об’єктивні складові самого рішення: цілі, ситуації, проблеми, обмеження, можливості, альтернативи, мотиви, ризики тощо [3].

Т. О. Кожан розглянув особливості застосування дескрипторів і поведінкових індикаторів у формуванні компетентностей персоналу, розробив методику оцінювання рівня їх розвитку у фахівців [6]. К. Б. Козак визначив роль лідерських якостей у керівництві персоналом підприємства [7].

Виділення невирішених раніше частин загальної проблеми. Незважаючи на значний вклад учених в розвиток науки про особливості мислення, невирішеними залишаються питання управлінського мислення керівників як основи корпоративного розвитку підприємств.

Виклад основного матеріалу. Проблема співвідношення мислення і знання була поставлена науковцями у вигляді парадоксального питання: що краще - мислити чи знати? Прагнучи виділити в мисленні творчий феномен, здатність мислячого суб'єкта відкривати нове, психологи протиставили 
продуктивне мислення репродуктивному, заснованому на минулому досвіді (знанні). Вони експериментально обгрунтували тезу про те, що минулий досвід $є$ гальмом, що перешкоджає баченню нового. На противагу таким дослідженням ми вважаємо, що будь-яке мислення формується на основі минулих знань, враховує їх та без з використання знань мислення взагалі $є$ неможливим.

Мислення є процесом формування складних зв'язків між стимулами і реакціями, становлення практичних умінь і навичок, пов'язаних з розв’язанням завдань [8].

У сучасній науці «мислення» визначається як процес пізнавальної діяльності людини, що характеризується узагальненим і опосередкованим відображенням дійсності, є вищою формою творчої активності, яка породжує розв'язання нового науково-прикладного завдання.

Мислення пов'язане 3 постійною зміною умов, в яких людина перебуває, воно є особливим видом інтелектуальної діяльності і передбачає формування дій і операцій пізнавального характеру.

Управлінське мислення проявляється у вирішенні проблемних завдань, які часто відрізняються неповними даними або дефіцитом інформації є важливою передумовою ефективного здійснення професійної діяльності менеджера.

Основними видами мислення є: теоретичне та практичне; репродуктивне i продуктивне (творче); наочно-образне, словесно-логічне i наочно-дійове; аналітичне (логічне, рекурсивне) i інтуїтивне; дивергентне і конвергентне.

$\square$ теоретичне мислення спрямоване на виявлення абстрактних закономірностей i правил, для здійснення системного аналізу розвитку професійної діяльності;

практичне мислення пов'язане 3 цілісним баченням ситуації, прогнозуванням їі зміни, постановкою цілей, формування планів і проектів професійної діяльності;

репродуктивне мислення відтворює способи і прийоми професійної діяльності за взірцем;

продуктивне (творче) мислення, проявляється у виявленні нових стратегій, які забезпечують ефективність праці і протистояння екстремальним ситуаціям;

наочно-образне мислення передбачає візуалізацію ситуації, де фахівець хоче отримати результат своєї професійної діяльності, а наочно дійове мислення передбачає повторюваність побачених дій;

аналітичне (логічне, рекурсивне) мислення характеризується розгорнутими в часі розумовими операціями, представленими у свідомості менеджера, а інтуїтивне мислення менеджера відрізняється швидкістю протікання, відсутністю чітко виражених етапів і мінімальною усвідомленістю;

конвергентне мислення передбачає вибір з безлічі варіантів єдино вірного;

дивергентне - передбачає варіювання рішень проблеми в залежності від ситуації.

Управління відноситься до професійної діяльності, ефективність здійснення якої в значній мірі залежить від управлінського мислення. Тому для визначення сутності управлінського мислення менеджеру потрібно брати до уваги не тільки особливості його професійної діяльності, а й умови, в яких ця діяльність здійснюється.

До особливостей професійної діяльності менеджера відносяться: різноманітність завдань; багатоваріантність рішень проблем без єдино правильного алгоритму; часові обмеження процесу прийняття рішень; різноманітність зовнішніх i внутрішніх умов, що впливають на розвиток виробничої системи; відсутність повної, достовірної та сучасної інформації для розв'язання управлінських завдань; взаємозалежність прийнятих рішень, негативні наслідки, що можуть наступити у разі вчинення управлінських помилок.

На основі досліджень змісту завдань, що розв'язуються менеджерами різного рівня учені зробили висновок, що у сучасного менеджера має бути сформовано економічне мислення, як «опосередковане і узагальнене відображення економічної дійсності, що включає, по-перше, пізнання системи об'єктивних економічних законів, категорій і концепцій; по-друге, засвоєння отриманих знань, їх перетворення в переконання, вміння і навички (логічні форми) мислення, мотиви діяльності; по-третє, реалізацію цих переконань, навичок і мотивів в економічній поведінці» [3].

Таким чином, управлінське мислення менеджера характеризується пізнанням суті, виявленням закономірностей, аналізом, узагальненням, систематизацією одержуваної інформації та прийняттям управлінських рішень, на основі професійних знань і узагальнення управлінського досвіду, 
отриманого з власної діяльності і спостережень за діяльністю інших фахівців.

Управлінське мислення:

- концентрується на особистості менеджерів у відношенні до колег і працівників, складається на основі стратегічних планів, характеризується різноманітністю режимів роботи і форм функціонування і реалізує потреби як споживачів так і персоналу;

- має на меті орієнтацію менеджера на створення максимально ефективних умов організації виробничого процесу, що забезпечують розвиток управління;

- змінюється залежно від ролі і місця менеджера в системі управління. Воно повинно пропорційно позначатися на зміні його управлінського мислення і навпаки, зміна управлінського мислення менеджера має сприяти зміні його статусу і становища в системі управління компанією;

- $\epsilon$ дивергентним потребує постійного оновлення змісту, форм і засобів управлінської діяльності, а також участі менеджера в інноваційній діяльності;

- характеризується нестандартністю завдань і проблем, які вирішуються менеджером в процесі розвитку сучасних соціально-економічних умов;

- вимагає творчого підходу.

На розвиток управлінського мислення впливає:

- професійна самостійність як здатність виконувати вимоги, висунуті професією, вміння планувати, організовувати, регулювати і контролювати свою діяльність, проявляти ініціативу;

- логічність, оперативність та креативність розумових процесів майбутнього фахівця, які проявляються в умінні швидко знаходити рішення професійних завдань, в оригінальності i нестандартності цих рішень;

- професійна мобільність як здатність до прийняття швидких раціональних рішень, готовності до змін ситуації;

- комунікативність, яка відображає спрямованість особистості на спілкування, зацікавленість в людях, толерантність до них;

- відповідальність за свої рішення і результати своєї діяльності;

- схильність менеджера до навчання. Довгий час в науці панувала думка, згідно 3 якою схильність до навчання має місце лише в ранні періоди життя людини (в дитинстві і юності). Однак в останні десятиліття з'явилося досить велика кількість досліджень, що підтверджують розвиток дорослої людини в періоди зрілості і доводять можливість іiі навчання протягом усього життя. У процесі навчання людина засвоює знання, розвиваючи себе.

- здоров'я як основа збереження та розвитку психічних та фізіологічних функцій, оптимальної працездатності та соціальної активності.

Висновки та пропозиції. На основі вищесказаного, можна стверджувати, що розвиток управлінського мислення менеджера $є$ цілеспрямованим, спеціально організованим процесом вдосконалення прийнятих рішень на основі якісних змін його розумової діяльності, при безперервному збагаченні його знаннями в професійній сфері з опорою на професійний досвід керівника.

До особливостей управлінського мислення менеджера відносяться його постійний зв'язок 3 активною зміною умов, в яких менеджер знаходиться; необхідністю вирішення проблемної ситуації.

Закономірностями розвитку управлінського мислення $є$ те що, менеджера можливо навчити, однак рівень його сприйнятливості до навчання різний у різні вікові періоди, а вдосконалення методів навчання створює потенційні можливості розумового розвитку, реалізація яких відбувається при активному застосуванні освоєні різних видів професійної діяльності на основі отриманих знань, набутого досвіду та якості розумової діяльності менеджера.

\section{Джерела та література}

1. Гальперин П. Я. Развитие исследований по формированию умственных действий. Психологическая наука в СССР. 1959. Т. 1. С. 441-469.

2. Джулакидзе Е., Барбакадзе Е. Правомерность управленческих решений и компетенция менеджеров малого бизнеса. Вісник Харківського національного університету імені ВН Каразіна. Серія «Економічна». 
2017. №. 93. C. 18-22.

3. Свтушенко Г. І., Вітренко Л. О. Шляхи формування професійної компетентності майбутнього менеджера. Збірник наукових праць Національного університету державної податкової служби України. 2013. №. 1. С. 69-78.

4. Заяць В. М. Роль інформаційних технологій у формуванні стратегічного мислення менеджера. Актуальні проблеми економіки. 2009. №. 6. С. 96.

5. Кожан Т. О. Компетентнісні засади моделювання діяльності менеджера з персоналу. Зб. наук. праць: Формування ринкової економіки. Спец. вип. Праця в XXI столітті: новітні тенденції, соціальний вимір, інноваційний розвиток: у 2 т. Т. 1. Київ: КНЕУ. 2012. Т. 660. С. 72.

6. Козак К. Б. Роль лідерства в системі управління персоналом на підприємстві. Економіка харчової промисловості. 2013. №. 3. С. 24-28.

7. Коленда Н. В. Шляхи підвищення конкурентоспроможності робочої сили.Економічний форум. 2011. - T. 1. C. 53-59

8. Леонтьев А.Н. Деятельность. Сознание. Личность. Москва: Академия, 2004. 352 с.

9. Теплов Б.М. Проблемы индивидуальных различий. Москва: Изд.АПН, 1961.

10. Рубинштейн С.Л. Бытие и сознание. Москва: Изд.АПН, 1957. 377 .

11. Цюрко І. А. Модель идеального руководителя отдела персонала. Бизнес информ. 2013. №. 12. С. $372-$

\section{References}

1. Halperin P. E. (1959). Development of research on the formation of mental actions Psychological science in the USSR. Vol. 1, 441-469.

2. Dzhulakidze, E., \& Barbakadze, E. (2017). Lawfulness of management decisions and competence of small business managers. Bulletin of the Karazin Kharkiv National University. Economic Series, (93), 18-22.

3. Yevtushenko, GI, \& Vitrenko, LO (2013). Directionss of organization of professional competence of the future manager. Proceedings of the National University of the State Tax Service of Ukraine, (1), 69-78.

4. Zait, W. M. (2009). The information technology in the organization of strategic thinking of the manager. Current Problems of Economics, (6), 96.

5. Kozhan, T. O. (2012). Competent principles of modeling of activity of the manager. Coll. Sciences. works: Formation of market economy. Spec. vol. Work in the 21st Century: Recent Trends, Social Dimension, Innovative Development: in 2 vols. T. 1. K .: KNEU, 660, 72.

6. Kozak, K. B. (2013). Leadership in the enterprise management system. Food Economics, (3), 24-28.

7. Kolenda, N. W. (2011). How to increase the competitiveness of the workforce. Economic Forum, 1, 53-59.

8. AN Leont'ev. (2004). Activity. Consciousness. Personality. Moscow: Academy, 352

9. Teplov BM (1961). Problems of individual differences. Moscow: APN,

10. Rubinstein SL (1957). Being and consciousness. Moscow: Publisher APN

11. Turko, I. A. (2013). The model of the perfect head of the HR department. Business Inform, (12), 372-377.

Стаття надійшла до редакції 10.06.2020 р. 